\title{
VASCULAR DYSFUNCTION IN THE $\alpha$-GALACTOSIDASE A-KNOCKOUT MOUSE IS AN ENDOTHELIAL CELL-, PLASMA MEMBRANE-BASED DEFECT
}

\author{
James L Park, ${ }^{*}$ Steven E Whitesall, ${ }^{\dagger}$ Louis G D’Alecy, ${ }^{\dagger \S}$ Liming Shu* and James A Shayman* \\ *Division of Nephrology, Department of Internal Medicine, University of Michigan Medical Center, ${ }^{\dagger}$ Department of Molecular \\ and Integrative Physiology, ${ }^{\ddagger}$ Department of Surgery, University of Michigan Medical School, Ann Arbor and \\ ${ }^{\S}$ Department of Surgery, William Beaumont Hospital, Royal Oak, Michigan, USA
}

\section{SUMMARY}

1. Fabry disease results from an $X$-linked mutation in the lysosomal $\alpha$-galactosidase A (Gla) gene. Defective Gla results in multi-organ accumulation of neutral glycosphingolipids (GSLs), especially in the vascular endothelium, with the major GSL accumulated being globotriaosylceramide (Gb3). Excessive endothelial Gb3 accumulation is associated with increased thrombosis, atherogenesis and endothelial dysfunction. However, the mechanism(s) by which endothelial dysfunction occurs is unclear. The purpose of the present study was to further characterize the vasculopathy associated with a murine model of Fabry disease.

2. Vascular reactivity was performed in vessels from wildtype $\left(\mathrm{Gla}^{+/ 0}\right)$ and Gla-knockout $\left(\mathrm{Gla}^{-/ 0}\right)$ mice. Conscious blood pressure and heart rate were measured in $\mathrm{Gla}^{+/ 0}$ and $\mathrm{Gla}^{-/ 0}$ mice by telemetry.

3. The present study demonstrates that vascular smooth muscle (VSM) contractions to phenylephrine and serotonin, but not to U46619, were blunted in $\mathrm{Gla}^{-10}$ mice. Endotheliumdependent contraction and receptor-mediated endotheliumdependent relaxation to acetylcholine were significantly attenuated in vessels from $\mathrm{Gla}^{-/ 0}$ mice. However, receptor-independent endothelium-dependent relaxation to the calcium ionophore ionomycin remained intact in vessels from $\mathrm{Gla}^{-/ 0}$ mice. Furthermore, VSM reactivity was normal in aortas from $\mathrm{Gla}^{-/ 0}$ mice in the absence of endothelium. These changes in vascular function were observed without changes in whole-animal blood pressure or heart rate.

4. These results suggest that the vasculopathy associated with Fabry disease is localized to the endothelium, despite the accumulation of GSLs throughout the vasculature.

Key words: endothelium, Fabry disease, $\alpha$-galactosidase A, globotriaosylceramide.

Correspondence: James A Shayman, University of Michigan, 1560 MSRB2, 1150 W Medical Center Drive, Ann Arbor, MI 48109-5676, USA. Email: jshayman@umich.edu

Received 20 November 2007; revision 16 March 2008; accepted 3 April 2008.

(C) 2008 The Authors

Journal compilation @ 2008 Blackwell Publishing Asia Pty Ltd

\section{INTRODUCTION}

Fabry disease, a rare lysosomal storage disorder, results from a deficiency in the lysosomal hydrolase $\alpha$-galactosidase A (Gla). ${ }^{1,2}$ The multi-organ accumulation of neutral glycosphingolipids (GSLs) with $\alpha$-galactosyl linkages, primarily globotriaosylceramide (Gb3), is the consequence of deficient lysosomal Gla activity. ${ }^{3,4}$ Because the disease is a recessive $\mathrm{X}$-linked disorder, hemizygous males are more severely affected by the disease and premature mortality is the result of the development of renal insufficiency and end-stage renal disease, as well as cardiovascular and cerebrovascular complications. ${ }^{5,6}$

The basis for these cardio- and cerebrovascular complications associated with Fabry disease may be derived, in part, from endothelial dysfunction associated with Gb3 accumulation in vascular endothelium. To date, previous studies have demonstrated Gb3 accumulation in both vascular smooth muscle (VSM) and endothelium in the vasculature of Gla-knockout $\left(\mathrm{Gla}^{-10}\right)$ mice, ${ }^{7,8}$ a murine model for Fabry disease. ${ }^{9}$ The increased vascular accumulation of Gb3 has been associated with an increased propensity for thrombosis, ${ }^{7,10}$ as well as increased atherogenesis, ${ }^{11}$ both of which are associated with endothelial dysfunction.

Excess endothelial Gb3 is believed to contribute to endothelial dysfunction associated with Fabry disease ${ }^{12}$ and Heare et al. demonstrated that blunted endothelium-dependent relaxation is associated with increased vascular Gb3 accumulation in older (19 months old) $\mathrm{Gla}^{-/ 0}$ mice. ${ }^{13}$ The purpose of the present study was to further characterize the vasculopathy associated with a murine model of Fabry disease. Reactivity was performed in isolated vessels from wild-type $\left(\mathrm{Gla}^{+/ 0}\right)$ and $\mathrm{Gla}^{-/ 0}$ mice. Our results demonstrate that vascular contractility to phenylephrine and serotonin, but not to U46619, were blunted. Endothelium-dependent contraction and relaxation to acetylcholine (ACh) also were attenuated, whereas receptor-independent endothelium-dependent relaxation remained intact in $\mathrm{Gla}^{-/ 0}$ mice. Furthermore, vascular reactivity was normalized in aortas from $\mathrm{Gla}^{-/ 0}$ mice after removal of the endothelium. These changes in vascular function were evident despite non-significant changes in consciously measured blood pressure and heart rate. These results suggest that vasculopathy in this model of Fabry disease is localized to the endothelium despite the accumulation of GSLs throughout the vasculature. More importantly, these observations suggest that the endothelial defect may stem from excess GSLs affecting receptor coupling, thereby extending our understanding of how excess endothelial GSL accumulation may have a functional impact on vascular function and pharmacology. 


\section{METHODS}

\section{Mice}

Male C57Bl/6 mice (wild-type or $\mathrm{Gla}^{+/ 0} ; 12-20$ weeks old) were obtained from Charles River (Wilmington, MA, USA) or Jackson Laboratories (Bar Harbor, ME, USA). Male Gla-knockout $\left(\mathrm{Gla}^{-10}\right)$ mice $^{9}$ were bred from mice provided by Drs Ashok Kulkarni and Roscoe Brady (National Institutes of Health, Bethesda, MD, USA). These mice were back-crossed at least five generations to the $\mathrm{C} 57 \mathrm{~B} 1 / 6$ strain. All mice were maintained on normal chow in specific pathogen-free facilities.

The procedures performed in mice were in accordance with guidelines of the University of Michigan Committee on the use and care of animals. The University of Michigan Unit for Laboratory Animal Medicine provided veterinary care. The University of Michigan is accredited by the American Association of Laboratory Animal Care. The animal care and use programme conformed to the standards in The Guide for the Care and Use of Laboratory Animals (Department of Health, Education and Welfare Publication No. (NIH) 86-23; http://www.nap.edu/readingroom/books/labrats/).

\section{Direct blood pressure and heart rate measurements with radiotelemetry}

Blood pressure and heart rate were measured in $\mathrm{Gla}^{+/ 0}$ and $\mathrm{Gla}^{-/ 0}$ mice as described previously. ${ }^{14}$ Briefly, the left common carotid artery was cannulated with the catheter of a telemetric blood pressure transducer (model TAP20-C10; Data Sciences International, St Paul, MN, USA), securing the body of the device in the abdominal cavity. Diastolic, systolic and mean arterial pressures, as well as heart rate, were collected every 10 min continuously for 3 weeks, beginning immediately after implantation. At the end of 3 weeks, three consecutive $28 \mathrm{~h}$ periods were averaged from each mouse and a group mean was calculated. The rate-pressure product $\left(\mathrm{mVO}_{2}\right)$, an indicator of myocardial oxygen consumption, was calculated from systolic pressure $\times$ heart rate.

\section{Isometric force measurements}

Vascular rings (2-3 $\mathrm{mm}$ in length), with or without endothelium, were mounted in a myograph system (Danish Myo Technology, Aarhus, Denmark) and bathed with warmed $\left(37^{\circ} \mathrm{C}\right)$, aerated $\left(95 \% \mathrm{O}_{2} / 5 \% \mathrm{CO}_{2}\right)$ physiological salt solution (PSS; composition (in mmol/L): $\mathrm{NaCl} 130 ; \mathrm{KCl} 4.7 ; \mathrm{KHPO}_{4}$ 1.18; $\mathrm{MgSO}_{4}$ 1.17; $\mathrm{CaCl}_{2}$ 1.6; $\mathrm{NaHCO}_{3}$ 14.9; dextrose 5.5; $\mathrm{CaNa}_{2}$ EDTA 0.03). Carotid rings were denuded of endothelium using a human hair; thoracic aortic rings were denuded of endothelium by perfusing the rings with $100 \mu \mathrm{L}$ of $0.1 \%$ Triton in phosphate-buffered saline (PBS). ${ }^{15}$ Carotid rings were set at $250 \mathrm{mg}$ passive tension, whereas thoracic aortic rings were set at $700 \mathrm{mg}$ passive tension. These passive tensions were chosen based on previous studies in the carotid artery ${ }^{16}$ and thoracic aorta. ${ }^{17}$ Arterial preparations were equilibrated for $1 \mathrm{~h}$, with washes every $20 \mathrm{~min}$. Prior to experimental protocols, rings were subjected to a wake-up protocol consisting of two consecutive contractions with KPSS (composition (in mmol/L): $\mathrm{NaCl} 14.7$; $\mathrm{KCl} 100 ; \mathrm{KHPO}_{4} 1.18 ; \mathrm{MgSO}_{4} 1.17 ; \mathrm{CaCl}_{2} 1.6 ; \mathrm{NaHCO}_{3}$ 14.9; dextrose 5.5; $\mathrm{CaNa}_{2}$ EDTA 0.03) and phenylephrine (PE; $10^{-6} \mathrm{~mol} / \mathrm{L}$ ), with washes between each KPSS contraction. After the PE contraction reached a plateau in the thoracic aortas, endothelial integrity was tested with $10^{-5} \mathrm{~mol} / \mathrm{L} \mathrm{ACh}$. The carotid rings were not exposed to ACh during the wake-up protocol because previous exposure of the arterial preparations to ACh or sodium nitroprusside (SNP) desensitizes the preparations to endothelium-dependent contractions. $^{18}$

\section{Experimental protocols}

\section{Endothelium-dependent contraction}

Carotid arteries were used to evaluate endothelium-dependent contractions because aortas do not have as robust an endothelium-dependent contraction as do carotid arteries. ${ }^{19}$ All equilibration and reactivity in the carotid rings (KPSS- and ACh-induced contractions) were performed in the presence of $3 \times 10^{-4} \mathrm{~mol} / \mathrm{L} N^{\mathrm{G}}$-nitro-L-arginine (L-NNA). After the wake-up protocol was performed, the PE contraction was washed out. Because of the biphasic nature of the ACh-mediated contraction, only a single concentration of ACh $\left(10^{-5} \mathrm{~mol} / \mathrm{L}\right)$ was used on the arterial preparations. ${ }^{19} \mathrm{~A}$ total of 10 mice was used to determine reactivity in the carotid arteries.

\section{Vascular smooth muscle contractility}

Thoracic aortas were used to evaluate VSM reactivity in endothelium-intact rings in the presence or absence of $3 \times 10^{-4} \mathrm{~mol} / \mathrm{L}$ L-NNA or in endotheliumdenuded rings. After the wake-up protocol, cumulative concentrations of $\mathrm{PE}\left(10^{-9}\right.$ to $\left.10^{-5} \mathrm{~mol} / \mathrm{L}\right)$, serotonin $\left(5-\mathrm{HT} ; 10^{-9}\right.$ to $\left.10^{-5} \mathrm{~mol} / \mathrm{L}\right)$ or the prostaglandin (PG) $\mathrm{H}_{2} /$ thromboxane (TX) $\mathrm{A}_{2}$ (TP) receptor agonist U46619 (10 $10^{-11}$ to $3 \times 10^{-7} \mathrm{~mol} / \mathrm{L}$ ) were added to the bath to establish a concentrationresponse curve. Contractions to PE, 5-HT or U46619 were expressed as a percentage of the second KPSS contraction. Reactivity to 5-HT and U46619 was determined in a group of aortas different from those used to investigate PE reactivity.

\section{Endothelium-dependent and-independent relaxation}

In rings of thoracic aorta in which a PE concentration-response curve was constructed, the $\mathrm{PE}$ contraction was washed out and the $\mathrm{EC}_{80}$ was calculated for $\mathrm{PE}$ in each individual ring. The individual $\mathrm{EC}_{80}$ values for $\mathrm{PE}$ were used to contract individual rings, which were allowed to reach a stable plateau response. Acetylcholine $\left(10^{-10}\right.$ to $\left.10^{-5} \mathrm{~mol} / \mathrm{L}\right)$, ionomycin $\left(10^{-10}\right.$ to $3 \times$ $\left.10^{-7} \mathrm{~mol} / \mathrm{L}\right)$ or SNP $\left(10^{-11}\right.$ to $\left.10^{-6} \mathrm{~mol} / \mathrm{L}\right)$ was added cumulatively to the bath to examine endothelium-dependent (ACh and ionomycin) or -independent (SNP) relaxation. Acetylcholine, ionomycin and SNP relaxation was expressed as a percentage of the contraction to the $\mathrm{EC}_{80}$ of PE. Reactivity to ACh and SNP was determined in the same rings, whereas ionomycin reactivity was determined in separate rings that did not receive ACh or SNP. Separate reactivity to all agonists also was examined in the presence of L-NNA $\left(10^{-4} \mathrm{~mol} / \mathrm{L}\right)$. In addition, $\mathrm{PE}, \mathrm{ACh}$ and SNP reactivity was determined again in separate endothelium-denuded rings.

\section{Chemicals}

Phenylephrine, 5-HT, ACh, SNP, L-NNA, Triton and all salts for PSS were purchased from Sigma Chemical (St Louis, MO, USA). U46619 was purchased from Cayman Chemical (Ann Arbor, MI, USA). Ionomycin was purchased from Calbiochem (La Jolla, CA, USA).

\section{Data and statistical analysis}

Agonist $\mathrm{EC}_{50}$ values were calculated using non-linear regression analysis with the algorithm (effect $=$ maximum response $/ 1+\left(\mathrm{EC}_{50} /\right.$ agonist concentration)) in the computer program GraphPad Prism (San Diego, CA, USA). Hill slope values were also derived from GraphPad Prism. The $\mathrm{EC}_{80}$ values for PE were calculated from the equation:

$$
\log \mathrm{EC}_{50}=\log \mathrm{EC}_{\mathrm{F}}-(1 / \text { Hill slope }) \times \log (\mathrm{F} /(100-\mathrm{F}))
$$

where $\mathrm{F}=80$.

Data are expressed as the mean \pm SEM. Blood pressure, heart-rate and ratepressure products were analysed using two-way ANOva. Concentrationresponse data were analysed using two-way ANOva to compare the concentration-response curves between groups. Bonferonni's post hoc test was used to assess differences at individual points on the concentration-response curves if the results of the two-way ANOva comparison between curves were $P<0.05$. One-way ANOVA was used to evaluate differences between groups in endothelium-dependent contractions. Differences in KPSS contractions, $\mathrm{EC}_{50}$ and $\mathrm{E}_{\max }$ between two groups were analysed by Student's $t$-test. $P<0.05$ was considered significant. 

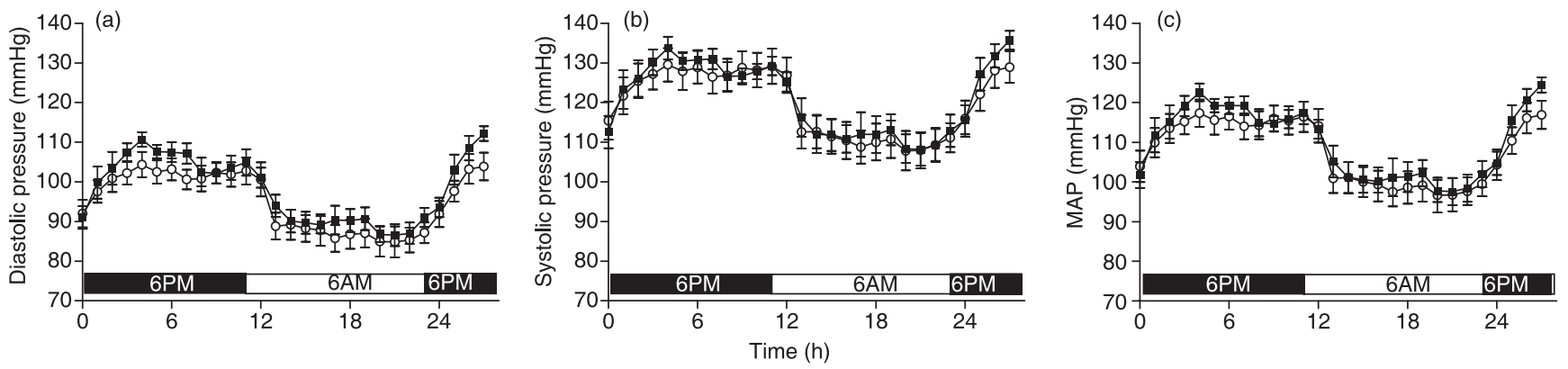

Fig. 1 Conscious (a) diastolic, (b) systolic and (c) mean arterial (MAP) blood pressures measured during a $28 \mathrm{~h}$ light-dark cycle by telemetry in wild-type $\left(\mathrm{Gla}^{+/ 0} ; n=8 ; \mathbf{\square}\right)$ or Gla-knockout $\left(\mathrm{Gla}^{-10} ; n=9\right.$; O) mice. $P>0.05$ by two-way ANOvA.
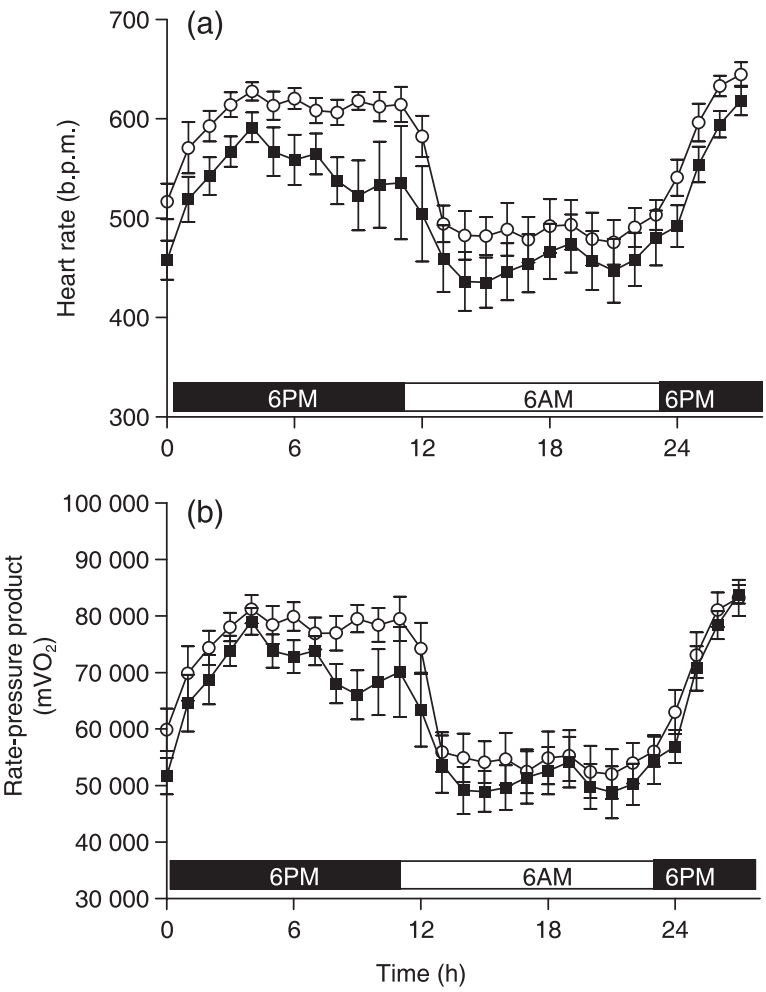

Fig. 2 (a) Heart rate and (b) calculated myocardial oxygen consumption $\left(\mathrm{mVO}_{2}\right)$ or rate-pressure product obtained from measurements derived from a telemetric blood pressure transducer in wild-type $\left(\mathrm{Gla}^{+/ 0} ; n=8 ; \mathbf{\square}\right)$ or Glaknockout $\left(\mathrm{Gla}^{-10} ; n=9 ; \bigcirc\right)$ mice. $P>0.05$ by two-way ANOva.

\section{RESULTS}

\section{Blood pressure and heart rate in $\mathrm{Gla}^{+/ 0}$ and $\mathrm{Gla}^{-10}$ mice}

Blood pressure and heart rate measured in $\mathrm{Gla}^{+/ 0}$ and $\mathrm{Gla}^{-/ 0}$ mice are shown in Figs 1 and 2. Diastolic (Fig. 1a), systolic (Fig. 1b) and mean arterial pressure (Fig. 1c) fluctuated due to circadian rhythms, but did not differ between the two groups over the $28 \mathrm{~h}$ period measured, suggesting the $\mathrm{Gla}^{-/ 0}$ mice were not hypertensive. Heart rate (Fig. 2) also fluctuated throughout the $28 \mathrm{~h}$ period due to circadian rhythms. Heart rate in $\mathrm{Gla}^{-10}$ mice was higher compared with $\mathrm{Gla}^{+/ 0}$ mice during the dark cycle, but the difference was not statistically significant. The rate-pressure product $\left(\mathrm{mVO}_{2}\right)$, a calculated index of myocardial oxygen consumption (Fig. 2b), also tended to be higher in $\mathrm{Gla}^{-/ 0}$ mice compared with $\mathrm{Gla}^{+/ 0}$ mice during the dark
Table 1 Potency of agonists in vascular reactivity of thoracic aortas with an intact endothelium from wild-type $\left(\mathrm{Gla}^{+/ 0}\right)$ or Gla-knockout $\left(\mathrm{Gla}^{-10}\right)$ mice

\begin{tabular}{lll}
\hline Agonist & \multicolumn{2}{c}{$-\log \mathrm{EC}_{50}(\mathrm{~mol} / \mathrm{L})$} \\
& \multicolumn{1}{c}{$\mathrm{Gla}^{+/ 0}$} & \multicolumn{1}{c}{$\mathrm{Gla}^{-10}$} \\
\hline PE & $6.99 \pm 0.05(16)$ & $6.72 \pm 0.05^{*}(16)$ \\
$5-\mathrm{HT}$ & $7.08 \pm 0.03(8)$ & $6.89 \pm 0.04^{*}(8)$ \\
U46619 & $8.77 \pm 0.02(8)$ & $8.70 \pm 0.02^{*}(8)$ \\
ACh & $7.43 \pm 0.05(7)$ & $7.37 \pm 0.10(7)$ \\
Ionomycin & $7.98 \pm 0.03(6)$ & $8.01 \pm 0.02(6)$ \\
SNP & $8.27 \pm 0.10(7)$ & $7.93 \pm 0.05^{*}(7)$ \\
\hline
\end{tabular}

Data are the mean \pm SEM, with the number of animals given in parentheses. $* P<0.05$ compared with $\mathrm{Gla}^{+/ 0}$ (Student's $t$-test).

$\mathrm{EC}_{50}$ values are expressed as the $-\log \mathrm{EC}_{50}$ for each agonist.

PE, phenylephrine; ACh, acetylcholine; 5-HT, serotonin; SNP, sodium nitroprusside.

cycle, although the difference was not significant, suggesting that hearts in $\mathrm{Gla}^{-/ 0}$ mice may be working harder to maintain perfusion pressure.

\section{Vascular contractility with PE, 5-HT and U46619}

\section{Phenylephrine}

The vascular contraction mediated by $100 \mathrm{mmol} / \mathrm{L}$ KPSS was equivalent in aortas from $\mathrm{Gla}^{+/ 0}$ and $\mathrm{Gla}^{-/ 0}$ mice $(1708 \pm 107 \mathrm{vs}$ $1496 \pm 93 \mathrm{mg}$, respectively; $n=16 ; P>0.05)$. In the presence of LNNA, the KPSS-induced contractions in $\mathrm{Gla}^{+/ 0}(n=12)$ and $\mathrm{Gla}^{-/ 0}$ $(n=13)$ mice were $2078 \pm 99$ and $2056 \pm 93 \mathrm{mg}$, respectively $(P>0.05)$. After endothelial denudation, KPSS-induced contractions in $\mathrm{Gla}^{+/ 0}$ and $\mathrm{Gla}^{-/ 0}$ mice were $1065 \pm 123$ and $1007 \pm 118 \mathrm{mg}$, respectively $(n=5 ; P>0.05)$.

Phenylephrine caused a concentration-dependent contraction in isolated endothelium-intact aortic rings from both $\mathrm{Gla}^{+/ 0}$ and $\mathrm{Gla}^{-/ 0}$ mice (Fig. 3). Phenylephrine contractility in untreated, endotheliumintact vessels (Fig. 3a) was approximately twofold less sensitive in aortas from $\mathrm{Gla}^{-/ 0}$ compared with $\mathrm{Gla}^{+/ 0}$ mice (Table 1). In addition, maximal contraction $\left(\mathrm{E}_{\mathrm{max}}\right)$ to $\mathrm{PE}$ in aortas from $\mathrm{Gla}^{-10}$ mice was significantly less than that in aortas from $\mathrm{Gla}^{+/ 0}$ mice $(92.9 \pm 3.7 \mathrm{vs}$ $107.9 \pm 4.0 \%$, respectively; $P<0.05)$. Phenylephrine contractility in the presence of L-NNA (Fig. 3b) was still less sensitive ( 1.6fold less) in aortas from $\mathrm{Gla}^{-10}$ compared with $\mathrm{Gla}^{+/ 0}$ mice (Table 2), 

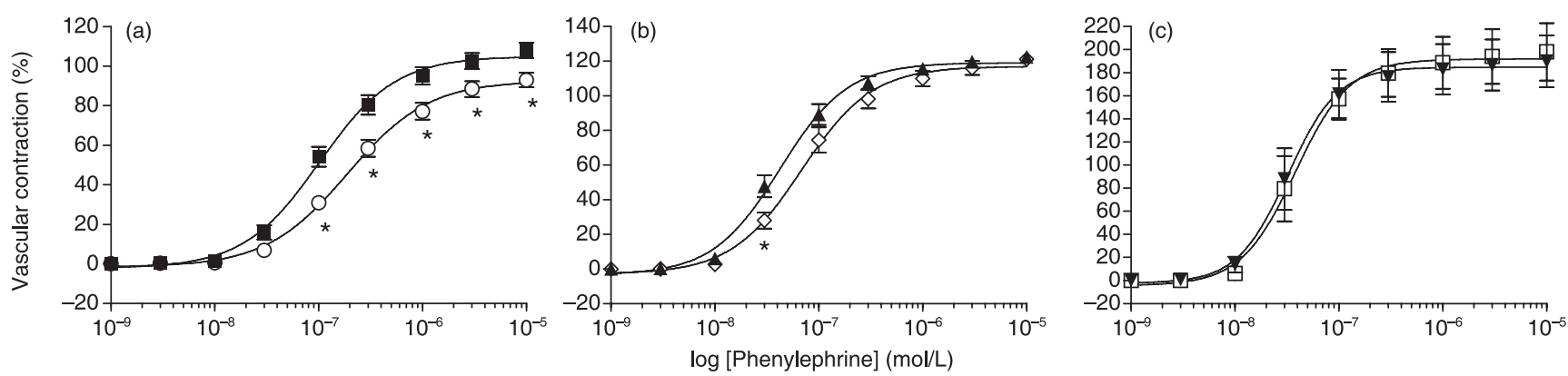

Fig. 3 Phenylephrine-mediated vascular contraction in endothelium-intact aortic rings from wild-type $\left(\mathrm{Gla}^{+/ 0}\right.$; filled symbols) or Gla-knockout (Gla ${ }^{-10}$; open symbols) mice (a) alone without any pharmacological intervention, (b) in the presence of $10^{-4} \mathrm{~mol} / \mathrm{L} N^{\mathrm{G}}$-nitro-L-arginine or (c) in endothelium-denuded preparations. Data are expressed as a percentage of the contraction elicited by $100 \mathrm{mmol} / \mathrm{L} \mathrm{KCl}$-containing physiological salt solution and show the mean $\pm \mathrm{SEM}$ $(n=5-16) . * P<0.05$ compared with $\mathrm{Gla}^{+/ 0}$ (two-way ANOVA followed by Bonferonni's post hoc test).

Table 2 Potency of agonists in vascular reactivity of thoracic aortas with an intact endothelium from wild-type $\left(\mathrm{Gla}^{+/ 0}\right)$ or Gla-knockout $\left(\mathrm{Gla}^{-10}\right)$ mice in the presence of $3 \times 10^{-4} \mathrm{~mol} / \mathrm{L} N^{\mathrm{G}}$-nitro-L-arginine

\begin{tabular}{lll}
\hline Agonist & \multicolumn{2}{c}{$-\log \mathrm{EC}_{50}(\mathrm{~mol} / \mathrm{L})$} \\
& $\mathrm{Gla}^{+/ 0}$ & $\mathrm{Gla}^{-/ 0}$ \\
\hline PE & $7.37 \pm 0.04(12)$ & $7.17 \pm 0.05^{*}(13)$ \\
$5-\mathrm{HT}$ & $7.19 \pm 0.02(6)$ & $6.96 \pm 0.04^{*}(6)$ \\
$\mathrm{U} 46619$ & $9.08 \pm 0.03(6)$ & $8.95 \pm 0.03^{*}(6)$ \\
ACh & $6.57 \pm 0.20(7)$ & $6.76 \pm 0.31(7)$ \\
Ionomycin & $8.01 \pm 0.31(5)$ & $7.76 \pm 0.21(6)$ \\
SNP & $9.07 \pm 0.13(5)$ & $9.11 \pm 0.02^{*}(5)$ \\
\hline
\end{tabular}

Data are the mean \pm SEM, with the number of animals given in parentheses. $* P<0.05$ compared with $\mathrm{Gla}^{+/ 0}$ (Student's $t$-test).

$\mathrm{EC}_{50}$ values are expressed as the $-\log \mathrm{EC}_{50}$ for each agonist.

$\mathrm{PE}$, phenylephrine; ACh, acetylcholine; 5-HT, serotonin; SNP, sodium nitroprusside.

whereas maximal contraction to PE did not differ in $\mathrm{Gla}^{+/ 0}$ and $\mathrm{Gla}^{-/ 0}$ mice in the presence of L-NNA $(122.5 \pm 3.1$ vs $121.1 \pm 3.6 \%$, respectively; $P>0.05$ ). Figure $3 \mathrm{c}$ shows $P E$ reactivity in endotheliumdenuded aortas from $\mathrm{Gla}^{+/ 0}$ and $\mathrm{Gla}^{-/ 0}$ mice. The PE-induced contractions were equivalent in aortas from $\mathrm{Gla}^{+/ 0}$ and $\mathrm{Gla}^{-/ 0}$ mice, as demonstrated by similar log $\mathrm{EC}_{50}$ values (Table 3), as well as equivalent $\mathrm{E}_{\max }$ values $(189.9 \pm 22.6$ vs $198.0 \pm 24.8 \%$, respectively; $P>0.05)$.

\section{Serotonin}

The vascular contraction mediated by $100 \mathrm{mmol} / \mathrm{L}$ KPSS for 5-HT and U46619 reactivity did not differ in endothelium-intact rings from $\mathrm{Gla}^{+/ 0}$ and $\mathrm{Gla}^{-/ 0}$ mice $(1225 \pm 109$ vs $1241 \pm 101 \mathrm{mg}$, respectively; $n=8 ; P>0.05)$. In addition, KPSS-induced contractions did not differ between $\mathrm{Gla}^{+/ 0}$ and $\mathrm{Gla}^{-/ 0}$ mice in the presence of L-NNA $(1414 \pm 60$ vs $1455 \pm 73 \mathrm{mg}$, respectively; $n=6 ; P>0.05)$ or after endothelium denudation (1064 \pm 76 vs $1043 \pm 82 \mathrm{mg}$, respectively; $n=5 ; P>0.05)$.

Serotonin produced concentration-dependent contraction of aortic rings (Fig. 4). Similar to PE, 5-HT contractility in endotheliumintact aortic rings (Fig. 4a) from $\mathrm{Gla}^{-/ 0}$ mice was significantly less than that of aortas from $\mathrm{Gla}^{+/ 0}$ mice (Table 1). Maximal contraction
Table 3 Potency of agonists in vascular reactivity of endothelium-denuded thoracic aortas from wild-type $\left(\mathrm{Gla}^{+/ 0}\right)$ or Gla-knockout $\left(\mathrm{Gla}^{-10}\right)$ mice

\begin{tabular}{lll}
\hline Agonist & \multicolumn{2}{c}{$-\log \mathrm{EC}_{50}(\mathrm{~mol} / \mathrm{L})$} \\
& \multicolumn{1}{c}{$\mathrm{Gla}^{+/ 0}$} & \multicolumn{1}{c}{$\mathrm{Gla}^{-10}$} \\
\hline PE & $7.49 \pm 0.10(5)$ & $7.42 \pm 0.10(5)$ \\
5 -HT & $7.38 \pm 0.04(6)$ & $7.15 \pm 0.05 *(5)$ \\
U46619 & $9.16 \pm 0.04(6)$ & $9.13 \pm 0.02(5)$ \\
ACh & $8.85 \pm 0.95(5)$ & $7.57 \pm 0.86(5)$ \\
Ionomycin & $\mathrm{ND}$ & $\mathrm{ND}$ \\
SNP & $9.07 \pm 0.02(5)$ & $9.11 \pm 0.02 *(5)$ \\
\hline
\end{tabular}

Data are the mean \pm SEM, with the number of animals given in parentheses. * $P<0.05$ compared with $\mathrm{Gla}^{+/ 0}$ (Student's $t$-test).

$\mathrm{EC}_{50}$ values are expressed as the $-\log \mathrm{EC}_{50}$ for each agonist.

PE, phenylephrine; ACh, acetylcholine; 5-HT, serotonin; SNP, sodium nitroprusside; ND, not determined.

$\left(\mathrm{E}_{\max }\right)$ to 5-HT in aortas from $\mathrm{Gla}^{-10}$ mice was significantly less than that of aortic rings from $\mathrm{Gla}^{+/ 0}$ mice $(119.4 \pm 5.7$ vs $138.3 \pm 2.9 \%$, respectively; $P<0.05$ ). In the presence of L-NNA (Fig. $4 \mathrm{~b}$ ), the difference in $\mathrm{E}_{\max }$ between $\mathrm{Gla}^{+/ 0}$ and $\mathrm{Gla}^{-/ 0}$ mice was no longer significant $(116.3 \pm 1.7$ vs $108.1 \pm 5.3 \%$, respectively; $P>0.05)$, but the difference in sensitivity was maintained (Table 2). Similarly, when the endothelium was removed (Fig. 4c), the $\mathrm{E}_{\max }$ to 5-HT was no longer significantly different between $\mathrm{Gla}^{+/ 0}$ and $\mathrm{Gla}^{-/ 0}$ mice $(161.1 \pm 5.9$ vs $162.8 \pm 12.2 \%$, respectively; $P>0.05$ ); however, unlike responses to $\mathrm{PE}$, the $\log \mathrm{EC}_{50}$ to 5-HT in endothelium-denuded rings remained less in $\mathrm{Gla}^{-/ 0}$ mice than in $\mathrm{Gla}^{+/ 0}$ mice (Table 3).

\section{The TP receptor agonist $U 46619$}

The third vasopressor tested in the present study, namely U46619, also caused concentration-dependent contractions of aortic rings from both $\mathrm{Gla}^{+/ 0}$ and $\mathrm{Gla}^{-/ 0}$ mice (Fig. 5). However, $\mathrm{E}_{\max }$ contractility did not differ between $\mathrm{Gla}^{+/ 0}$ and $\mathrm{Gla}^{-/ 0}$ mice regardless of the presence of an intact endothelium (177.9 \pm 5.3 vs $169.4 \pm 7.0 \%$, respectively; $P>0.05$; Fig. 5a:), L-NNA $(132.7 \pm 4.0$ vs $142.4 \pm 4.7 \%$, respectively; $P>0.05$; Fig. $5 \mathrm{~b}$ ) or after removal of the endothelium $(193.0 \pm 11.1$ vs $211.5 \pm 19.9 \%$, respectively; $P>0.05$; Fig. $5 \mathrm{c})$. The $\mathrm{EC}_{50}$ for $\mathrm{U} 46619$ in endothelium-intact aortic rings from 

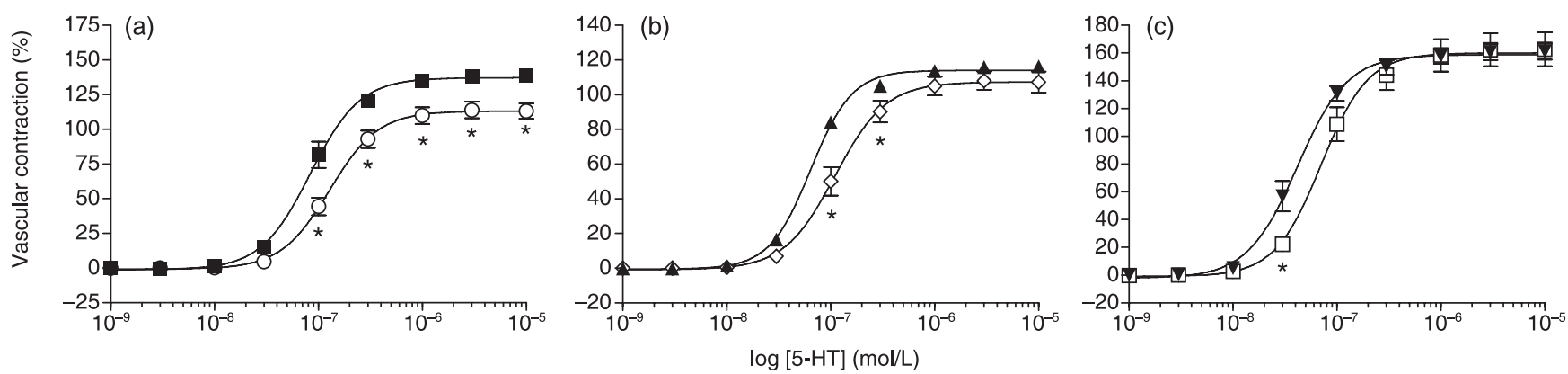

Fig. 4 Serotonin (5-HT)-mediated vascular contraction in endothelium-intact mouse aortic rings from wild-type (Gla ${ }^{+/ 0}$; filled symbols) or Gla-knockout $\left(\mathrm{Gla}^{-10}\right.$; open symbols) mice (a) alone without any pharmacological intervention, (b) in the presence of $10^{-4} \mathrm{~mol} / \mathrm{L} N^{\mathrm{G}}$-nitro-L-arginine or (c) in endotheliumdenuded preparations. Data are expressed as a percentage of the contraction elicited by $100 \mathrm{mmol} / \mathrm{L} \mathrm{KCl}$-containing physiological salt solution and show the mean $\pm \operatorname{SEM}(n=5-8) .{ }^{*} P<0.05$ compared with $\mathrm{Gla}^{+/ 0}$ (two-way ANOva followed by Bonferonni's post hoc test).
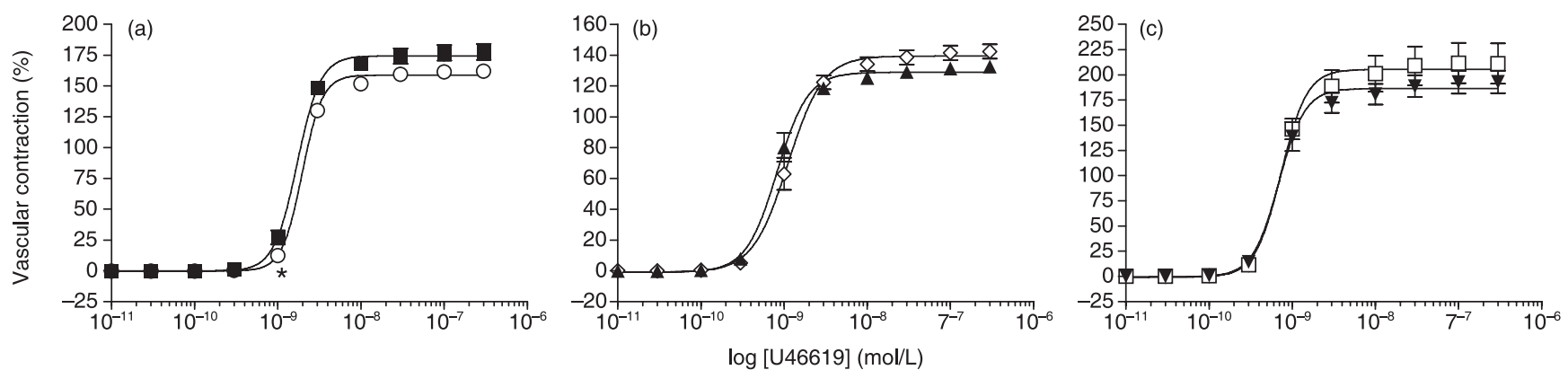

Fig. 5 Vascular contraction mediated by the thromboxane $A_{2}$ /prostaglandin $\mathrm{H}_{2}$ (TP) receptor agonist U46619 in endothelium-intact mouse aortic rings from wild-type $\left(\mathrm{Gla}^{+/ 0}\right.$; filled symbols) or Gla-knockout ( $\mathrm{Gla}^{-10}$; open symbols) mice (a) alone without any pharmacological intervention, (b) in the presence of $10^{-4} \mathrm{~mol} / \mathrm{L} N^{\mathrm{G}}$-nitro-L-arginine or (c) in endothelium-denuded preparations. Data are expressed as a percentage of the contraction elicited by $100 \mathrm{mmol} / \mathrm{L}$ $\mathrm{KCl}$-containing physiological salt solution and show the mean $\pm \mathrm{SEM}(n=5-8) . * P<0.05$ compared with Gla ${ }^{+/ 0}$ (two-way ANova followed by Bonferonni's post hoc test).

$\mathrm{Gla}^{-/ 0}$ mice was minimally different, yet still significant, compared with the $\mathrm{EC}_{50}$ for $\mathrm{U} 46619$ in similar preparations from $\mathrm{Gla}^{+/ 0}$ mice (Table 1). Similar observations were made for U46619 contractility in the presence of L-NNA (Table 2). However, removing the endothelium resulted in similar $\mathrm{EC}_{50}$ values for $\mathrm{U} 46619$ in aortic rings from both $\mathrm{Gla}^{+/ 0}$ and $\mathrm{Gla}^{-10}$ mice (Table 3).

\section{Endothelium-dependent contraction with ACh}

Endothelium-dependent contraction to ACh was examined in isolated carotid arteries from $\mathrm{Gla}^{+/ 0}$ and $\mathrm{Gla}^{-10}$ mice (Fig. 6). The carotid arteries were used because they display a much more robust endotheliumdependent contraction to ACh compared with the aorta. ${ }^{19}$ The KPSS-induced contractions in endothelium-intact carotid rings from $\mathrm{Gla}^{+/ 0}$ and $\mathrm{Gla}^{-10}$ mice were equivalent $(514 \pm 56$ vs $490 \pm 46 \mathrm{mg}$, respectively; $n=5)$. In carotid arteries, under baseline resting conditions, $\mathrm{ACh}\left(10^{-5} \mathrm{~mol} / \mathrm{L}\right)$, in the presence of $3 \times 10^{-4} \mathrm{~mol} / \mathrm{L} \mathrm{L}-\mathrm{NNA}$, caused a contraction that was absent in endothelium-denuded arteries. However, the endothelium-dependent contraction elicited by ACh was significantly less in carotid arteries from $\mathrm{Gla}^{-/ 0}$ mice ( $49 \%$ less) compared with $\mathrm{Gla}^{+/ 0}$ mice.

\section{Receptor-mediated endothelium-dependent relaxation with ACh}

Endothelium-dependent relaxation to ACh also was examined in aortas isolated from $\mathrm{Gla}^{+/ 0}$ and $\mathrm{Gla}^{-/ 0}$ mice and precontracted with

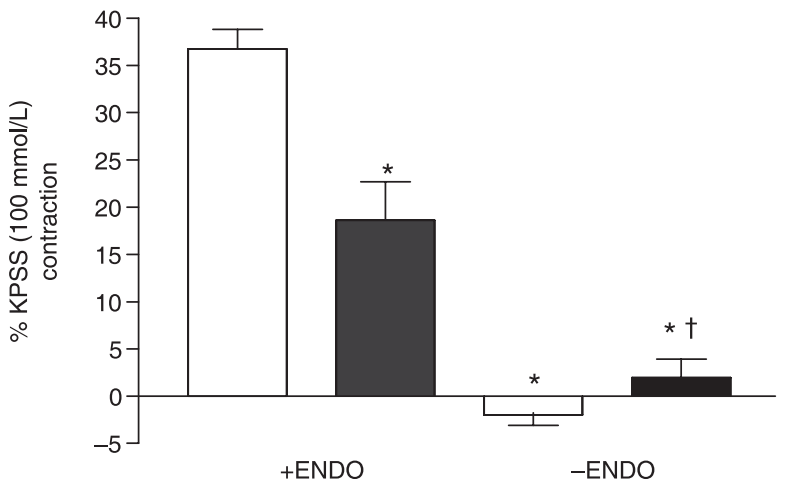

Fig. 6 Endothelium-dependent contraction mediated by $10^{-5} \mathrm{~mol} / \mathrm{L}$ acetylcholine in endothelium-intact (+ENDO) and -denuded (-ENDO) carotid artery rings from wild-type $\left(\mathrm{Gla}^{+/ 0} ; \square\right)$ or Gla-knockout $\left(\mathrm{Gla}^{-/ 0} ; \mathbf{\square}\right)$ mice in the presence of $3 \times 10^{-4} \mathrm{~mol} / \mathrm{L} N^{\mathrm{G}}$-nitro-L-arginine. Data are the mean $\pm \mathrm{SEM}$ ( $n=5$ in each group). $* P<0.05$ compared with $\mathrm{Gla}^{+/ 0} ;{ }^{\dagger} P<0.05$ compared with $\mathrm{Gla}^{+/ 0}-$ ENDO (one-way ANOva).

the $\mathrm{EC}_{80}$ for PE calculated individually for each ring on the basis of the $\mathrm{PE}$ concentration-response curve. Aortic rings from $\mathrm{Gla}^{-10}$ mice relaxed significantly less than rings from $\mathrm{Gla}^{+/ 0}$ mice $\left(\mathrm{E}_{\max } 62.5 \pm 6.3\right.$ vs $83.3 \pm 2.9 \%$, respectively; Fig. 7a). The ACh responses are endothelial nitric oxide synthase (eNOS) and endothelium dependent, because both L-NNA (Fig. 7b) and endothelium denudation (Fig. 7c) prevented any ACh-mediated relaxation in precontracted aortic rings from $\mathrm{Gla}^{+/ 0}$ and $\mathrm{Gla}^{-/ 0}$ mice. 

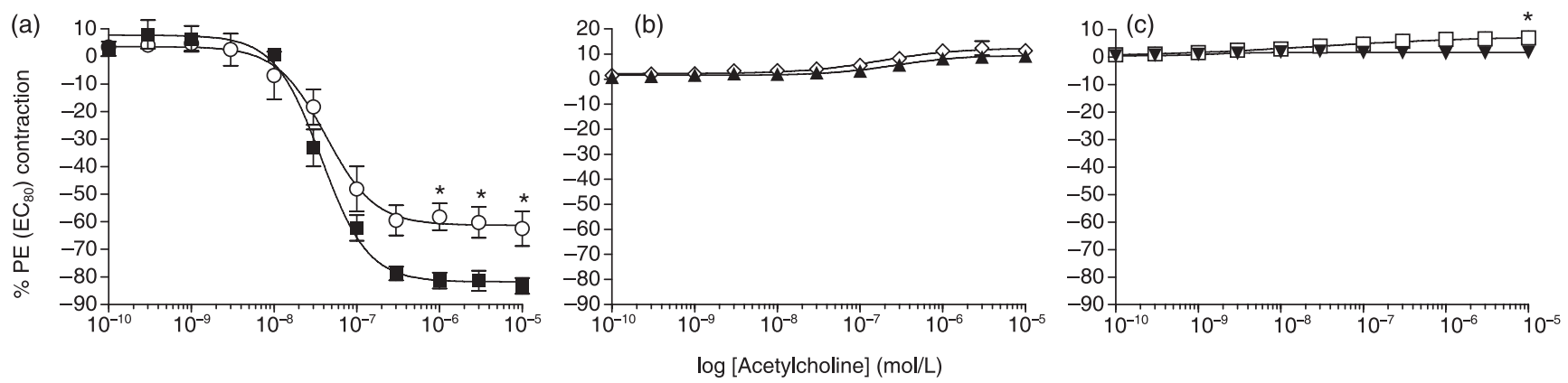

Fig. 7 Acetylcholine-mediated endothelium-dependent relaxation in endothelium-intact mouse aortic rings from wild-type (Gla ${ }^{+/ 0}$; filled symbols) or Glaknockout $\left(\mathrm{Gla}^{-10}\right.$; open symbols) mice (a) alone without any pharmacological intervention, (b) in the presence of $10^{-4}$ mol/L $N^{\mathrm{G}}$-nitro-L-arginine or (c) in endothelium-denuded preparations. Data are expressed as a percentage of the contraction elicited by the $\mathrm{EC}_{80}$ for phenylephrine and show the mean $\pm \mathrm{SEM}$ $(n=5-7) . * P<0.05$ compared with $\mathrm{Gla}^{+/ 0}$ (two-way ANOva followed by Bonferonni's post hoc test).

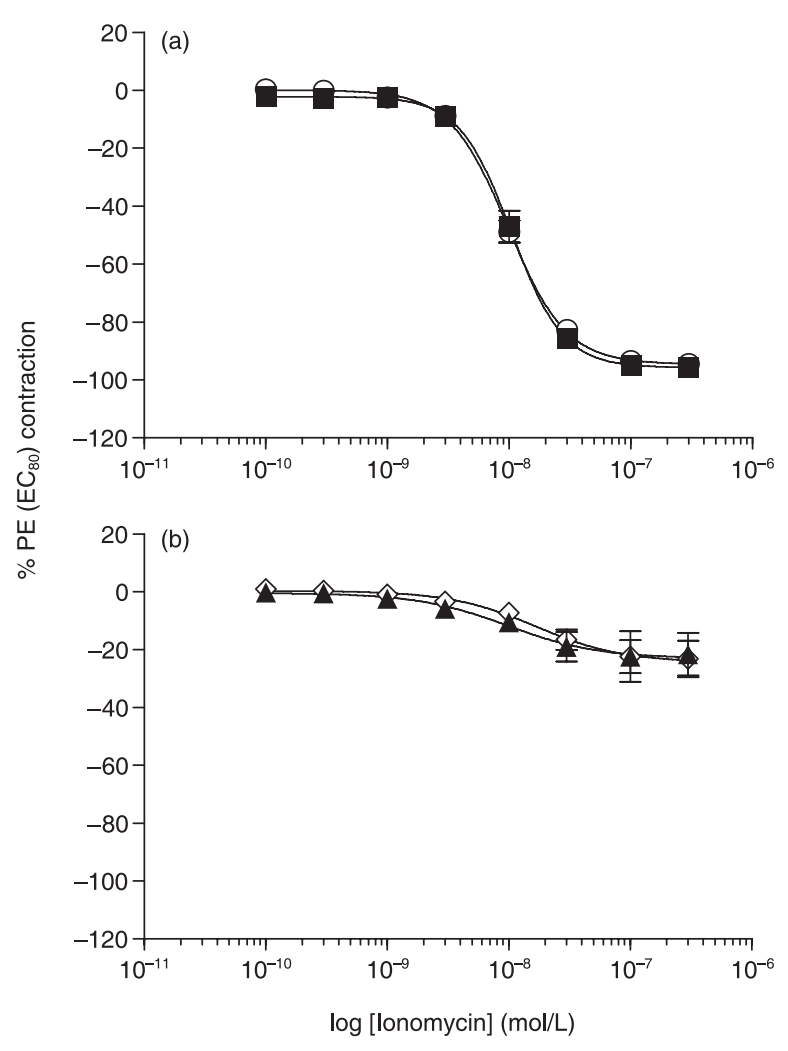

Fig. 8 Ionomycin-induced endothelial nitric oxide synthase-dependent relaxation in endothelium-intact aortic rings from wild-type $\left(\mathrm{Gla}^{+/ 0}\right.$; filled symbols) or Gla-knockout $\left(\mathrm{Gla}^{-10}\right.$; open symbols) mice precontracted with an $\mathrm{EC}_{80}$ concentration of phenylephrine (PE) (a) alone without any pharmacological intervention or (b) in the presence of $10^{-4} \mathrm{~mol} / \mathrm{L} N^{\mathrm{G}}$-nitro-Larginine. Data are the mean $\pm \operatorname{SEM}(n=5-6) . P>0.05$ (two-way ANOva).

\section{Non-receptor-mediated endothelium-dependent relaxation with ionomycin}

The calcium ionophore ionomycin was used to induce non-receptormediated eNOS-dependent relaxations in endothelium-intact vessels precontracted with an $\mathrm{EC}_{80}$ of $\mathrm{PE}$ (Fig. 8). Ionomycin-induced relaxation (Fig. 8a) did not differ between vessels from $\mathrm{Gla}^{+/ 0}$ $\left(\log \mathrm{EC}_{50}=-7.98 \pm 0.03 \mathrm{~mol} / \mathrm{L} ; \mathrm{E}_{\max }=95.5 \pm 2.1 \%\right)$ and $\mathrm{Gla}^{-/ 0}$ $\left(\log \mathrm{EC}_{50}=-8.01 \pm 0.02 \mathrm{~mol} / \mathrm{L} ; \mathrm{E}_{\max }=94.5 \pm 1.7 \%\right)$ mice. Ionomycin caused a slight relaxation in precontracted endothelium-intact aortic rings from $\mathrm{Gla}^{+/ 0}$ and $\mathrm{Gla}^{-/ 0}$ mice incubated with L-NNA (Fig. 8b), but no significant differences existed between the two groups in terms of the sensitivity or maximal response to ionomycin in the presence of L-NNA.

\section{Endothelium-independent relaxation with SNP}

Sodium nitroprusside mediated a concentration-dependent endothelium-independent relaxation in thoracic aortas isolated from $\mathrm{Gla}^{+/ 0}$ and $\mathrm{Gla}^{-/ 0}$ mice. In endothelium-intact rings, the SNP-induced relaxation was less in rings from $\mathrm{Gla}^{-/ 0}$ compared with $\mathrm{Gla}^{+/ 0}$ mice (Table 1). Vessels exposed to the NOS inhibitor L-NNA were significantly more sensitive to SNP compared with respective vessels with an intact endothelium and in the absence of L-NNA (Table 2). Similarly, endothelium-denuded aortas exhibited increased sensitivity to SNP compared with their untreated, endothelium-intact counterparts (Table 3) and were similar in sensitivity to L-NNAtreated vessels.

\section{DISCUSSION}

Fabry disease has a complex cardiovascular phenotype. Premature mortality is more often the result of stroke and myocardial infarctions. ${ }^{20}$ Informative clinical studies in Fabry disease patients have documented both macro- and microvascular dysfunction, suggesting that the pathophysiology may be highly complex. ${ }^{21,22}$ The $\alpha$ galactosidase A knockout mouse $\left(\mathrm{Gla}^{-/ 0}\right)$ provides a potentially useful tool to study these cardiovascular phenomena. Indeed, our group has reported that these mice are more susceptible to oxidant-induced thrombosis and accelerated atherogenesis. ${ }^{7,11}$ In the present study, we used this model to ascertain the role of the endothelium in large vessel reactivity.

We report several novel observations in this $\mathrm{Gla}^{-/ 0}$ murine model of Fabry disease. First, abnormal vasopressor contractility to PE and 5-HT; aortas from $\mathrm{Gla}^{-10}$ mice are less sensitive to these agents than wild-type $\left(\mathrm{Gla}^{+/ 0}\right)$ aortas but exhibit normal responses to the TP receptor agonist or when the endothelium is removed. Second, endothelium-dependent contraction is significantly less in $\mathrm{Gla}^{-/ 0}$ compared with $\mathrm{Gla}^{+/ 0}$ carotid arteries. Third, impaired endotheliumdependent relaxation is not observed when a calcium ionophore is used to mediate endothelium-dependent relaxation. These observations are important because the defects observed in this murine model of Fabry disease demonstrate a complexity of the reactivity 
that can be attributed entirely to the endothelium, even though elevated Gb3 levels occur in the other vascular cell types. ${ }^{7,13}$

In many vascular diseases, such as hypertension and diabetes, VSM vasopressor sensitivity is increased, whereas endotheliumdependent relaxation is diminished. ${ }^{23-26}$ Our data were surprising because abnormal endothelium-dependent relaxation was observed but a concomitant increased sensitivity to vasopressor activity was absent in the presence of endothelium, as illustrated by decreased sensitivity to PE or 5-HT, whereas TP receptor-mediated VSM contraction with U46619 was similar in $\mathrm{Gla}^{-/ 0}$ and $\mathrm{Gla}^{+/ 0}$ mice.

How this anomaly developed in our mouse model of Fabry disease is unclear, but we speculate on several mechanisms that may partially explain our observations. If basal NO production is higher in $\mathrm{Gla}^{-10}$ mice, then VSM contraction would be inhibited. Furthermore, if agonist-stimulated NO production is less in $\mathrm{Gla}^{-/ 0}$ mice, for whatever reason, endothelium-dependent relaxation would also be inhibited or diminished. However, the persistence of decreased sensitivity to vasopressor in the presence of L-NNA does not support that hypothesis, suggesting that the endothelium may be producing another factor to cause endothelium-dependent relaxation after stimulation with ACh. Prostaglandin $\mathrm{I}_{2}$, which mediates endotheliumdependent relaxation by activation of cAMP in $\mathrm{VSM},{ }^{27}$ is a potential mechanism by which our anomalous reactivity may be occurring. However, whether cyclo-oxygenase-derived products have any role in the vascular dysfunction or are in some way regulated by glycosphingolipids is yet to be determined.

Alternatively, on a more cellular level, in cells subjected to pathologically increased levels of Gb3, excess Gb3 content may be present in compartments outside the lysosome, including lipid rafts or caveolae. Recently, we reported that $\mathrm{Gb} 3$ and other globo series GSLs are present in higher concentrations in caveolae from $\mathrm{Gla}^{-/ 0}$ compared with $\mathrm{Gla}^{+/ 0}$ endothelial cells. ${ }^{28}$ These changes in GSLs increase as a function of age and are accompanied by corresponding decreases in cholesterol. In addition, GSL concentrations in caveolae change dynamically after endothelial cells are exposed to recombinant $\alpha$-galactosidase A or the glucosylceramide synthase inhibitor D-threoethylenedioxyphenyl-2-palmitoylamino-3-pyrillidino-propanol. Modulation of cellular GSL content regulates bradykinin-induced src kinase and phospholipase $\mathrm{C} \gamma$ activation. ${ }^{29,30}$ Conversely, increased Gb3 accumulation in endothelial cells may inhibit receptor-induced signalling responsible for activation of eNOS. The observation of endothelium-dependent relaxation with the calcium ionophore ionomycin supports this potential mechanism because the ionophore relaxation is normal in aortas from $\mathrm{Gla}^{-/ 0}$ compared with $\mathrm{Gla}^{+/ 0}$ mice, whereas the receptor-induced endothelium-dependent relaxation to $\mathrm{ACh}$ is attenuated in aortas from $\mathrm{Gla}^{-10}$ mice.

Because these caveolar domains are enriched with and regulate eNOS, accumulated caveolar GSL associated with Fabry disease may conceivably alter eNOS activation by one of two mechanisms. First, eNOS and caveolin interactions are affected by excess Gb3 or a related sphingolipid or, alternatively, by secondary changes in other raft-associated lipids. Second, receptor coupling to downstream mediators may be affected, because sphingolipid, as well as cholesterol, content in lipid rafts or caveolae can modulate the fluidity of these signalling 'hot spots' ${ }^{31}$ Our data appear to support the latter mechanism because eNOS activation independent of a receptor is normal, suggesting that any interactions between eNOS and caveolin- 1 are not affected by increased caveolar Gb3 content. However, further studies are needed to demonstrate that receptor coupling is affected by excess endothelial Gb3 in this mouse model of Fabry disease. Our endothelium-dependent contraction and relaxation data combined are consistent with the hypothesis that receptor coupling is affected in this mouse model of Fabry disease, because both are attenuated in $\mathrm{Gla}^{-10}$ mice and, in particular, because endothelium-dependent contractions, in the face of endothelial dysfunction, should be augmented.

Our data indicate that, whatever the mechanism may be, changes in vascular function in the $\mathrm{Gla}^{-10}$ mice are localized to the endothelium. This conclusion is supported by two main observations. First, most of the vascular contractility to vasopressor is close to normal after endothelium denudation. Second, endothelium-dependent contraction is significantly attenuated in $\mathrm{Gla}^{-/ 0}$ mice, a phenomenon that is due to the paracrine release of a TP receptor agonist from the endothelium. ${ }^{32}$ However, direct stimulation of VSM contraction with the TP receptor agonist U46619 did not reveal any differences between $\mathrm{Gla}^{-/ 0}$ and $\mathrm{Gla}^{+/ 0}$ mice.

In conclusion, we demonstrate that the vasculopathy associated with $\mathrm{Gla}^{-/ 0}$ mice occurs at a younger age than reported previously ${ }^{13}$ and that the early vasculopathy is localized to the endothelium. Importantly, the vasculopathy reported here may be a result of impaired receptor signalling rather than impaired eNOS activity. These findings provide insight into how early vasculopathy may develop in Fabry disease, but they also suggest that glycosphingolipid metabolism may play a subtle, yet significant, role in the regulation of receptor-mediated signalling.

\section{ACKNOWLEDGEMENTS}

This work was supported by National Institutes of Health grant 5RO1DK055823-06. Some of this work was reported at the International Society of Nephrology Forefronts in Nephrology Conference on Endothelial Biology (March 2006).

\section{REFERENCES}

1. Kint JA. The enzyme defect in Fabry's disease. Nature 1970; 227: 1173.

2. Kint JA. Fabry's disease: Alpha-galactosidase deficiency. Science 1970; 167: 1268-9.

3. Sweeley CC, Klionsky B. Fabry's disease: Classification as a sphingolipidosis and partial characterization of a novel glycolipid. $J$. Biol. Chem. 1963; 238: 3148-50.

4. Brady RO, Gal AE, Bradley RM, Martensson E, Warshaw AL, Laster L. Enzymatic defect in Fabry's disease. Ceramidetrihexosidase deficiency. N. Engl. J. Med. 1967; 276: 1163-7.

5. Desnick RJ, Ioannou YA, Eng CM. $\alpha$-Galactosidase A deficiency: Fabry disease. In: Scriver CR, Beaudet AL, Sly WS, Valle D (eds). The Metabolic and Molecular Bases of Inherited Disease, 8th edn. McGraw-Hill, New York. 2001; 3733-74.

6. Desnick RJ, Banikazemi M, Wasserstein M. Enzyme replacement therapy for Fabry disease, an inherited nephropathy. Clin. Nephrol. 2002; 57: $1-8$.

7. Eitzman DT, Bodary PF, Shen Y et al. Fabry disease in mice is associated with age-dependent susceptibility to vascular thrombosis. $J$. Am. Soc. Nephrol. 2003; 14: 298-302.

8. Shu L, Murphy HS, Cooling L, Shayman JA. An in vitro model of Fabry disease. J. Am. Soc. Nephrol. 2005; 16: 2636-45.

9. Ohshima T, Murray GJ, Swaim WD et al. Alpha-Galactosidase A deficient mice: A model of Fabry disease. Proc. Natl Acad. Sci. USA 1997; 94: 2540-4.

10. Shen Y, Bodary PF, Vargas FB et al. Alpha-galactosidase A deficiency leads to increased tissue fibrin deposition and thrombosis in mice homozygous for the factor V Leiden mutation. Stroke 2006; 37: 1106-8. 
11. Bodary PF, Shen Y, Vargas FB et al. Alpha-galactosidase A deficiency accelerates atherosclerosis in mice with apolipoprotein $\mathrm{E}$ deficiency. Circulation 2005; 111: 629-32.

12. Moore DF, Gelderman MP, Fuhrmann SR, Schiffmann R, Brady RO, Goldin E. Fabry disease and vascular risk factors: Future strategies for patient-based studies and the knockout murine model. Acta Paediatr. Suppl. 2006; 95: 69-71.

13. Heare T, Alp NJ, Priestman DA et al. Severe endothelial dysfunction in the aorta of a mouse model of Fabry disease: Partial prevention by $N$-butyldeoxynojirimycin treatment. J. Inherit. Metab. Dis. 2007; 30: 79-87.

14. Whitesall SE, Hoff JB, Vollmer AP, D'Alecy LG. Comparison of simultaneous measurement of mouse systolic arterial blood pressure by radiotelemetry and tail-cuff methods. Am. J. Physiol. Heart Circ. Physiol. 2004; 286: H2408-15.

15. Tang EH, Ku DD, Tipoe GL, Feletou M, Man RY, Vanhoutte PM. Endothelium-dependent contractions occur in the aorta of wild-type and $\mathrm{COX}_{2}{ }^{--}$knockout but not $\mathrm{COX} 1^{-1-}$ knockout mice. J. Cardiovasc. Pharmacol. 2005; 46: 761-5.

16. Faraci FM, Sigmund CD, Shesely EG, Maeda N, Heistad DD. Responses of carotid artery in mice deficient in expression of the gene for endothelial NO synthase. Am. J. Physiol. 1998; 274: H564-70.

17. Park JL, Loberg RD, Duquaine D et al. GLUT4 facilitative glucose transporter specifically and differentially contributes to agonistinduced vascular reactivity in mouse aorta. Arterioscler. Thromb. Vasc. Biol. 2005; 25: 1596-602.

18. Tang EH, Feletou M, Huang Y, Man RY, Vanhoutte PM. Acetylcholine and sodium nitroprusside cause long-term inhibition of EDCFmediated contractions. Am. J. Physiol. Heart Circ. Physiol. 2005; 289: H2434-40.

19. Zhou Y, Varadharaj S, Zhao X, Parinandi N, Flavahan NA, Zweier JL. Acetylcholine causes endothelium-dependent contraction of mouse arteries. Am. J. Physiol. Heart Circ. Physiol. 2005; 289: H1027-32.

20. Shayman JA, Killen PD. Fabry disease. In: Mount DB, Pollak MJ (eds). Molecular and Genetic Basis of Renal Disease. Saunders/Elsevier, Philadelphia. 2008; Ch. 13.
21. Elliott PM, Kindler H, Shah JS et al. Coronary microvascular dysfunction in male patients with Anderson-Fabry disease and the effect of treatment with alpha galactosidase A. Heart 2006; 92: 35760.

22. Moore DF, Kaneski CR, Askari H, Schiffmann R. The cerebral vasculopathy of Fabry disease. J. Neurol. Sci. 2007; 257: 258-63.

23. Guo Z, Su W, Allen S et al. COX-2 up-regulation and vascular smooth muscle contractile hyperreactivity in spontaneous diabetic $\mathrm{db} / \mathrm{db}$ mice. Cardiovasc. Res. 2005; 67: 723-35.

24. Linder AE, Weber DS, Whitesall SE, D'Alecy LG, Webb RC. Altered vascular reactivity in mice made hypertensive by nitric oxide synthase inhibition. J. Cardiovasc. Pharmacol. 2005; 46: 438-44.

25. Pannirselvam M, Verma S, Anderson TJ, Triggle CR. Cellular basis of endothelial dysfunction in small mesenteric arteries from spontaneously diabetic $\left(\mathrm{db} / \mathrm{db}^{-1-}\right)$ mice: Role of decreased tetrahydrobiopterin bioavailability. Br. J. Pharmacol. 2002; 136: 25563.

26. Pannirselvam M, Wiehler WB, Anderson T, Triggle CR. Enhanced vascular reactivity of small mesenteric arteries from diabetic mice is associated with enhanced oxidative stress and cyclooxygenase products. Br. J. Pharmacol. 2005; 144: 953-60.

27. Shepherd JT, Katusic ZS. Endothelium-derived vasoactive factors. I. Endothelium-dependent relaxation. Hypertension 1991; 18 (Suppl. III): III-76-85.

28. Shu L, Shayman JA. Caveolin-associated accumulation of globotriaosylceramide in the vascular endothelium of alphagalactosidase A null mice. J. Biol. Chem. 2007; 282: 20 960-7.

29. Shu L, Lee L, Shayman JA. Regulation of phospholipase C-gamma activity by glycosphingolipids. J. Biol. Chem. 2002; 277: 18 447-53.

30. Shu L, Shayman JA. Src kinase mediates the regulation of phospholipase C-gamma activity by glycosphingolipids. J. Biol. Chem. 2003; 278: 31 419-25.

31. Brown DA, London E. Structure and function of sphingolipid- and cholesterol-rich membrane rafts. J. Biol. Chem. 2000; 275: 17 221-4.

32. Vanhoutte PM, Feletou M, Taddei S. Endothelium-dependent contractions in hypertension. Br. J. Pharmacol. 2005; 144: 449-58. 